\title{
Multiffaceted Chemistry Conceptual Profile of Selected Senior High School STEM Students from a Private School in Manila
}

\author{
Rick Jasper A. Carvajal \\ Br. Andrew Gonzales FSC College of Education, De La Salle University, 2401 Taft Avenue, Malate, Manila, \\ 1004, Metro Manila, Philippines
}

*Author to whom correspondence should be addressed; email: rick_carvajal@dlsu.edu.ph

\begin{abstract}
Chemistry has always been identified as a discipline with pluralistic characteristics. This implies that chemistry can be viewed differently based on one's conception, conceptual model, and conceptual change. Subsequently, this denotes into a diverse context, different profiles of conceptions, which then convey multifaceted view of the discipline. The polysemous view of chemistry was addressed and proposed into six chemistry conceptual profile zones - monist, epistemic, processual, pragmatic, aversive, and attractive. There is a need to recognize this and structure chemistry education based on conceptual profile, since the discipline is naturally complex, rich, and multifaceted. The objective of the study is to analyze, identify, and categorize the multifaceted conceptions in chemistry of selected senior high school STEM students enrolled in a certain private school in Manila City, under these six conceptual profile zones. More so, the study aims to determine the possible ways to improve the conceptions of students based on their own response and perspective. Descriptive qualitative research design through semantic thematic analysis and statistical inference using Chi-square of Goodness-of-Fit were employed to analyze the data. The result revealed that almost all of these $(n=57)$ selected SHS STEM students can conceptualize the epistemic view in the profile zone but not the other five. Based on the two themes generated, it can be implied that there is always an opportunity for critical reflection on how to reconceptualize the discipline and take chemistry into a more authentic field of science and science education.
\end{abstract}

Keywords: chemistry conception; chemistry conceptual profile; multifaceted conception; SHS STEM students

\section{INTRODUCTION}

The pluralistic characteristic of Chemistry as a discipline has always been viewed and identified by many. This means that chemistry has been depicted as a science of material alteration, a science of 
process of substance, a practical science, an academic science, a manufacturing science, and a central science (Schummer, Bensaude-Vincent, \& Tiggelen, 2008). For instance, the idea that chemistry illustrates both post-industrial and pre-industrial impressions (Sjostrom, 2006) or the idea that chemistry and technology can be combined together. This is known as technochemistry, which is one of the chemists' methods of knowing (Chamizo, 2013). Consequently, this implies that chemistry can be viewed differently based on one's conception, conceptual model, and conceptual change. Thus, this results into a diverse context and different profiles of conceptions, which yield to multifaceted view of the discipline.

Mortimer and El-Hani (1995; 2014) introduced the conceptual profile theory by integrating different philosophies and perspectives such as sociocultural and pragmatic view to the existing models of conceptual change. Conceptual profiling simply means providing the different views and perceptions of the people in representing the world. This is evident and is used in various contexts obviously intertwined in the ways of expression of a person. Hence, conceptual profiling acknowledges the polysemous view of chemistry, which were enriched and proposed by Freire and Amaral (2017) into six chemistry conceptual profile zones - monist, epistemic, processual, pragmatic, aversive, and attractive. A brief description of the modes of thinking of each zone in chemistry profile is presented in Table 1.

Table 1. Summary of the zones of the conceptual profile of chemistry

\begin{tabular}{ll}
\hline Zone & Modes of thinking \\
\hline Monist & Chemistry is everything and is all around us. Even people are not conscious \\
& about it, matter always exists and thus chemistry has existed since the origin of \\
the Universe. It is omnipresent. & Chemistry is a school subject. It is as a science of systematized body of \\
Epistemic & knowledge. It is understood as a theoretical framework, by the textbook, and \\
& seen as a difficult subject with abstract ideas. \\
Processual & Chemistry is a process that occurs with specific entities. It is the \\
& transformation and the creation of a body or a substance through a chemical \\
Pragmatic & Cheaction, resulting in the loss of some materials. \\
& and practical situations. Chemistry is what a chemist does as career, and this \\
Aversive & activity guided by policies, principles, and behaviors. \\
& Chemistry is associated with chemical pollution. It is related with a \\
& contaminating agent, malefic and lethal substance. It is the opposite of " $n a t u r a l$ \\
product" and tends to have a negative connotation to the word "chemical." It is \\
also the usual public view of chemistry. \\
Chemistry is an attraction and a connection. It is related with a feeling, a \\
Attractive \\
love, and a strong affinity between two people. This is known as perfect chemistry. \\
It is about the conception of values more than knowledge itself. It is also about \\
a successful interaction with other disciplines - psychological, sociological, \\
biological, etc.
\end{tabular}

Students are constantly experiencing difficulties in understanding the multifaceted concepts of chemistry. The major reason for this problem, as stated by Freire, Talanquer, and Amaral (2019), is that chemistry teachers themselves are unaware of chemistry conceptual profile zones and are struggling to productively incorporate contextualized instruction in their lessons. Recognition of the different facet zones in chemistry conception could direct teachers' attention to the development of more genuine and authentic learning experience in chemistry. This can be used as a framework for promoting action and thinking in chemistry education. 
There are related studies that aim to determine the conception of students in chemistry such as chemical solubility (Ebenezer \& Erickson, 1996), chemical change (Hesse \& Anderson, 1992), redox reaction (Adu-Gyamfi, Ampiah, \& Agyei, 2016) and secondary school chemistry (Osman \& Sukor, 2013). However, these studies are topic-specific and/or only pertain to junior high school chemistry. Subsequently, these are not based on multifaceted views of conceptions. There is a research gap in identifying the chemistry conceptions of senior high school STEM students in the Philippines, categorized based on various conceptual profile zones. This study initiated the recommendation of Freire, Talanquer, and Amaral last 2019 by analyzing the conceptual profile, which then helps SHS chemistry instructors to critically understand and problematize the discipline of chemistry, its instruction, and its purpose in the society.

The main objective of the study was to analyze and then identify the multifaceted conceptions in chemistry of selected senior high school STEM students through the six conceptual profile zones. Specifically, this sought answers to the following questions: (1) what are the chemistry conceptual profiles of selected senior high school STEM students?; (2) what are the possible ways to improve the conceptions of students based on their own response and perspective?; and (3) is there a significant difference between the observed frequency and the expected equal frequency distinctly prevalent in each zone?

\section{METHODOLOGY}

Selected Respondents and Data Gathering. A total of 57 grade 11 senior high school Science, Technology, Engineering, and Mathematics (STEM) students from the Basic Education Department in a non-sectarian private university located in Manila City, Philippines, participated in the study done in academic year 2019-2020. These were male and female students having an age range of 16 to 18. More so, these students were from two different classes of the teacher-researcher taking General Chemistry 1 as one of their specialized subjects for the second semester of the academic year. In this school, there were seven grade 11 STEM sections and another seven sections of grade 12, a total of fourteen classes in STEM with a class size of roughly forty students. Chemistry class highly involves in-depth lessons of general principles, concepts, and calculations in chemistry, which includes nature of matter, numbers and measurements, atoms and chemical nomenclature, mass relationships, chemical reactions and equations, stoichiometry, quantum mechanical model, periodicity, and other relevant topics (Department of Education, 2016).

Textual open-ended response of students was collected at the end of the semester in partial fulfillment of the course. Reviewed by inter-coders, questions briefly asked to the students were the following :

1. Whenever you hear the word "Chemistry", what really comes to your mind?

2. In your own point of view, what is Chemistry? Can you describe it?

3. In your own perception, how do you see Chemistry as a field?

4. Do you think your perception in Chemistry can still be changed? Why and how?

The first question pertains to the term Chemistry itself while the second elicits a response describing the said terminology. In addition, the third response of the student guides them to think about their perception of chemistry as a discipline. Finally, the last question lets the students reflect on their conception and its plausibility for change. Hereafter, these questions yielded to the students' conceptual profile. It is important to take note that these questions were non-leading to any conceptual profile zone, which avoids prejudice response from the participants.

Textual responses are classified to be participant-generated textual data (Fugard \& Potts, 2015) in which participants primarily recorded the response based on their own point of view in relation to a question list, either by writing or typing (Braun \& Clarke, 2013). Here, the data gathering was done 
asynchronously online using Google Form. Answering these questions took about five to fifteen minutes of participants' time. Since most of the participant are below legal age, consent from their parents was secured to conduct the study. Similarly, students were notified that the data gathered from them will be subjected to a research investigation confidentially.

Data Analysis. Descriptive qualitative research design and statistical inference were employed in the study. To have a reliable result, the explicit responses of the students were analyzed by two inter-coders through semantic approach (Caulfield, 2019), thematic analysis (Braun \& Clarke, 2013) and classify their chemistry conceptions based on the conceptual profile developed and empirically proposed by Freire and Amaral (2017). Appropriately, the fourth response of the students was further studied through semantic coding thematic analysis as well until theoretical saturation (Braun \& Clarke, 2013) was achieved, to determine possible ways in improving their own conception based on their own perspective. In qualitative analysis, theoretical saturation regards as a point in which data does not anymore generate new perspective from the participants - after which, themes can now be generated inductively or deductively using the codes.

After thematic analysis, frequency count of the occurrence of each conceptual profile zone was identified to determine the most and the least prevailing conceptions present in the responses of the participants. The frequency of the occurrence of each zone was counted distinctly per each student and not per manifested statement. For instance, in the responses of a certain student. there were four phrases or statements that evidently manifest as conceptions under Epistemic Zone while the two others as conceptions under Attractive Zone - this is counted as one for Epistemic Zone and another one for Attractive Zone only. In this way, the counted data was accurate and suitable for statistical inference. Hereafter, the observed frequency of the conceptions was analyzed through Chi-square of Goodness-of-Fit test. This statistical tool is used to test non-parametric data if the observed frequency is not significantly different to the expected frequency (Statistics Solution, 2020). It is expected to have an equal frequency count of zones to each other.

\section{RESULTS AND DISCUSSION}

The open-ended textual responses of students were analyzed, identified, and counted. Furthermore, themes generated from the answers were determined.

Analyzing and Identifying the Multifaceted Conceptions in Chemistry. Through the analysis of the open-ended textual response of students, the chemistry conceptions and their corresponding category under the six conceptual profile zones were identified. Some students have conceptions in chemistry under all the six profile zones. However, some conceptions of students are only limited to few or to one of the six zones. Sample responses are provided in Table 2-4 with their appropriate color codes as follow: monist, epistemic, processual, pragmatic, aversive, and attractive. 
Table 2. Sample of respondent's (Student A) textual responses showing only one conceptual profile zone.

\begin{tabular}{|c|c|c|c|c|}
\hline \multicolumn{4}{|c|}{ Response } & \multirow{2}{*}{ Remarks } \\
\hline Question 1 & Question 2 & Question 3 & Question 4 & \\
\hline $\begin{array}{l}\text { When I hear the word } \\
\text { Chemistry, the first } \\
\text { thing that comes into } \\
\text { my mind is elements. I } \\
\text { also think that this } \\
\text { subject is very hard to } \\
\text { understand and study. } \\
\text { But as time goes by, I } \\
\text { can really understand } \\
\text { some parts of the } \\
\text { lessons in this subject. }\end{array}$ & $\begin{array}{l}\text { I think that Chemistry is } \\
\text { a branch of science that } \\
\text { deals with matter and } \\
\text { elements. I also see it as } \\
\text { a very hard subject } \\
\text { because I can't } \\
\text { understand some parts } \\
\text { of it. Chemistry can also } \\
\text { be a core subject to } \\
\text { some stem-related } \\
\text { courses in college. }\end{array}$ & $\begin{array}{l}\text { I see Chemistry as an } \\
\text { essential subject that I } \\
\text { need to study because } \\
\text { of my preferred course } \\
\text { in college. I also see this } \\
\text { subject as a trial for the } \\
\text { next years of my } \\
\text { academic life. I think it } \\
\text { will help me a lot in } \\
\text { terms of my studies. }\end{array}$ & $\begin{array}{l}\text { I think that it can } \\
\text { change, it depends on } \\
\text { the way of teaching by } \\
\text { the professor. The way } \\
\text { of learning can change } \\
\text { by making the lessons } \\
\text { fun. It has really } \\
\text { changed for me because } \\
\text { of the way [my teacher] } \\
\text { is teaching. }\end{array}$ & $\begin{array}{c}\text { Zone of } \\
\text { conceptual } \\
\quad \text { profile } \\
\text { present } \\
\text { distinctly is: } \\
\text { Epistemic } \\
\text { only }\end{array}$ \\
\hline
\end{tabular}

Table 2 indicates the sample of Student A textual responses showing only one conceptual profile zone. Epistemic view of the discipline connotes chemistry as what-the-textbook-is-saying concept and sees it as a difficult school subject. According to the response, the student thought that chemistry is a very hard subject to understand and stated a basic textbook description of chemistry as a science that deals with matter and elements. Again, 56 out of 57 respondents have this view of chemistry (see Table 5).

Table 3. Sample of respondent's (Student B) textual responses showing all conceptual profile zones.

\begin{tabular}{|c|c|c|c|c|}
\hline \multicolumn{4}{|c|}{ Response } & \multirow{2}{*}{ Remarks } \\
\hline Question 1 & Question 2 & Question 3 & Question 4 & \\
\hline $\begin{array}{l}\text { Every time I hear the } \\
\text { word Chemistry, the } \\
\text { first thing that comes } \\
\text { into my mind is } \\
\text { particles, atoms, and } \\
\text { such. The reason why } \\
\text { these things are the first } \\
\text { things that I can think } \\
\text { of because, it is already } \\
\text { put into my mind, even } \\
\text { when I was in grade } \\
\text { school (young) studying } \\
\text { about Chemistry up } \\
\text { until now, that these } \\
\text { things are the ones that } \\
\text { cannot go unmentioned } \\
\text { from the topic. }\end{array}$ & $\begin{array}{l}\text { For me, Chemistry is a } \\
\text { science that is } \\
\text { everywhere in the world } \\
\text { around us. One thing is } \\
\text { that it involves many } \\
\text { things from the air we } \\
\text { breathe, the food we } \\
\text { eat, the medicines, and } \\
\text { more. I also think that } \\
\text { Chemistry is an } \\
\text { important field of } \\
\text { science since, medicine } \\
\text { cannot be made without } \\
\text { it, we won't know a } \\
\text { thing about what harms } \\
\text { that a certain chemical } \\
\text { does for us and how to } \\
\text { prevent it, and more } \\
\text { other things. }\end{array}$ & $\begin{array}{l}\text { I can see Chemistry as } \\
\text { one that mainly involves } \\
\text { working in a science } \\
\text { laboratory. But I think } \\
\text { that Chemistry is more } \\
\text { than just a branch of } \\
\text { Science that does } \\
\text { experiments. I can see it } \\
\text { as the one that connects } \\
\text { other branches of } \\
\text { science like, physics, } \\
\text { biology, and such. }\end{array}$ & $\begin{array}{l}\text { Yes. It can change in a } \\
\text { way that, I still have } \\
\text { little knowledge about } \\
\text { Chemistry, and this is } \\
\text { just only the beginning, } \\
\text { basics, or background } \\
\text { of it. I might learn so } \\
\text { much more when I go } \\
\text { to college or have a field } \\
\text { of work relating to it. } \\
\text { For now, I don't see } \\
\text { Chemistry that } \\
\text { interesting yet but, it } \\
\text { doesn't mean that I will } \\
\text { disregard learning more } \\
\text { from it. }\end{array}$ & 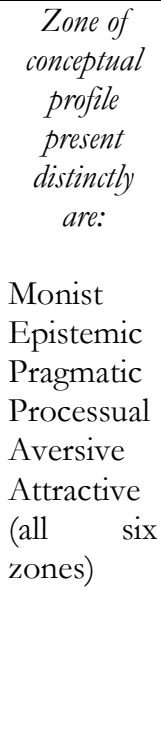 \\
\hline
\end{tabular}

Table 3 indicates the sample of Student B textual responses showing all conceptual profile zones. It is obvious that Student B has a broad view of chemistry encompassing all profile zones and not just an epistemic view. This response reveals a monist view of the discipline recognizing that chemistry is everywhere in the world around us. Likewise, this presents a pragmatic view since the student told something about the practical importance of chemistry in the field and science laboratory work. Moreover, the student acknowledged that chemistry is a field of process and its application in the medical field. The student also said the role of chemistry in prevention of certain harmful chemicals. These statements imply processual and aversive concepts, respectively. Additionally, Student B viewed chemistry's connection with other discipline: an under attractive zone conception. 
Table 4. Sample of respondent's (Student C) textual responses showing only few conceptual profile zones.

\begin{tabular}{|c|c|c|c|c|}
\hline \multicolumn{4}{|c|}{ Response } & \multirow{2}{*}{ Remarks } \\
\hline Question 1 & Question 2 & Question 3 & Question 4 & \\
\hline $\begin{array}{l}\text { What comes to my } \\
\text { mind whenever I hear } \\
\text { Chemistry is first that } \\
\text { it's all about chemicals. } \\
\text { Second is it's also about } \\
\text { formula and combining } \\
\text { chemicals. }\end{array}$ & $\begin{array}{l}\text { For me Chemistry is all } \\
\text { about learning how } \\
\text { things work. It also } \\
\text { serves as a bridge into } \\
\text { creating new things or } \\
\text { new chemicals. I think } \\
\text { without chemistry we } \\
\text { would not be able to } \\
\text { progress and innovate. }\end{array}$ & $\begin{array}{l}\text { I see chemistry as a field } \\
\text { for people who want to } \\
\text { take on a challenge. } \\
\text { Because chemistry isn't } \\
\text { an easy subject and } \\
\text { taking it as your field it } \\
\text { would be a challenge. }\end{array}$ & $\begin{array}{l}\text { Yes, because I just had a } \\
\text { short time in dealing } \\
\text { with chemistry. I still } \\
\text { believe that if I was } \\
\text { given a longer more } \\
\text { time with chemistry my } \\
\text { perception would } \\
\text { change. }\end{array}$ & $\begin{array}{c}\text { Zone of } \\
\text { conceptual } \\
\text { profile } \\
\text { present } \\
\text { distinctly } \\
\text { are: } \\
\text { Epistemic } \\
\text { Pragmatic } \\
\text { Processual }\end{array}$ \\
\hline
\end{tabular}

Table 4 indicates the sample of Student $C$ textual responses showing few conceptual profile zones. Most of the students' conceptual profile in chemistry is similar to this. Apparently, they have not shown all the six zones but just few. These results, Student A, B and C as examples, reveal that the conception of chemistry varies from one student to another. This finding is similar to some studies about chemistry alternative conceptions (Garnett \& Garnett, 1995), chemistry conceptions in different domains (Sadi, 2015), and survey of students' conceptions in chemistry (Chiu, 2005).

Frequency Count and Chi-square of Goodness-Of-Fit Result. The frequency for each conceptual profile zone was counted distinctly per student and not per occurrence in the response. See Table 2 as an example - a student has many phrases showing epistemic view, but this was only counted as one.

Table 5. The frequency count of the presence of conception under the six profile zones.

\begin{tabular}{lll}
\hline $\begin{array}{c}\text { Conceptual } \\
\text { Profile } \\
\text { Zone }\end{array}$ & \multicolumn{1}{c}{$\begin{array}{c}\text { Number of } \\
\text { student (n= 57) }\end{array}$} & Percentage \\
\hline Monist & 13 & $23 \%$ \\
Epistemic & 56 & $98 \%$ \\
Pragmatic & 37 & $65 \%$ \\
Processual & 27 & $47 \%$ \\
Aversive & 5 & $9 \%$ \\
Attractive & 22 & $39 \%$ \\
\hline
\end{tabular}

Table 6. Non-parametric Chi-square of Goodness-Of-Fit Result

\begin{tabular}{ll}
\hline & Frequency \\
\hline Chi-square & $61.700^{\mathrm{a}}$ \\
$\mathrm{df}$ & 5 \\
Asymp. Sig. & .000 \\
\hline
\end{tabular}

a. 0 cells $(.0 \%)$ have expected frequencies less than 5 . The minimum expected cell frequency is 26.7

Table 5 shows the frequency count of the presence of conception under the six profile zones. It is obvious that the epistemic zone is the most prevailing conception. Ninety-eight percent $(98 \%)$ of the students has this view of chemistry. Epistemic view of the discipline connotes chemistry as what-the-textbook-is-saying concept and sees it as a difficult school subject. Almost all of the students (56 out of $n=57$ ) attest that chemistry is a hard to understand subject, viewing that it is about: matter and its changes; elements on the periodic table and the combination of these element; and chemicals and chemical reactions. This result is not unusual because high school chemistry is a foundational introductory chemistry, which predominantly talks about science of abstractions and calculations in symbolic level with unfamiliar language (Cardellini, 2012). Though this is not the only reason, this conception might have made the view of the students to chemistry as a difficult subject (Osman \& Sukor, 2013). 
On the other hand, only five respondents out of 57 students have an aversive view of chemistry. Aversive zone of chemistry signifies a negative connotation about the term "chemical" and something that is very related to pollution. This result is comparable to a study that few of the students has an idea that chemistry is related to something poisonous, lethal, polluted, and contaminated (Freire \& Amaral, 2017). This conception of few students might have been provoked by the popular stereotype of "mad scientist" in fiction films that elicit the idea of destruction (Weingart, 2006).

Table 6 summarizes the non-parametric Chi-square of Goodness-Of-Fit result. With an alpha value of $5 \%$, the p-value is .000 implies that the null hypothesis should be rejected. There is a significant difference between the expected frequency (26.7) and the observed frequency. Hence, the frequency of students' conception in profile zone is not equal. This finding is parallel in Table 5 result, clearly confirming that there is no profile zone with the same frequency. Not even two zones have the same frequency. This also means that students may have various multifaceted chemistry conception, from one respondent to another.

Improving Chemistry Conception. After achieving the theoretical saturation in the thematic analysis using the sematic codes (Braun \& Clarke, 2013), two themes were identified based on the textual response of students: (1) increasing the engagement in chemistry improves conception and (2) taking higher or college chemistry expands chemistry knowledge.

Increasing the engagement in chemistry would improve conception in the said discipline. Pedagogically, there are many possible ways to increase engagement more than just through classroom interaction but also through other learning techniques, media, and ways, which affect conception. These may include everyday experiences, instructor's language (Demircioglu, Ayas \& Demircioglu, 2005), teacher's competency, chemistry references and textbook (Schmidt, Marohn, \& Harisson, 2007), alternative conception (Osman \& Sukor, 2013), identifying cognitive styles and cognitive structure of students (Atabek-Yigit, 2018) and undeniably teaching strategies and approaches (Ozmen, 2004). Nevertheless, it is important to know that not all of these techniques may help facilitate learning engagement in chemistry. Hence, instructional improvements should give emphasis on the appropriate and enriched teaching strategies and approaches in General Chemistry, as stated in a local study (Solis-Foronda, 2013).

On this account, innovation in chemistry teaching approaches and strategies should be one of the foci so that students may change their conception from monofaceted to multifaceted. To do this, an instructor must contextualize chemistry content in different ways especially socio-humanistic method and issue-based approach in teaching (Abd-El-Khalick, 2013). This would give opportunities to students to analyze and to perceive that chemistry changes through time, extending their concepts. Additionally, fostering both lower-order and higher-order cognitive skills of learners should be developed (Zoller \& Tsaparlis, 1997), since scientific literacy is a needed to function as a productive citizen in the society. This might manifest pragmatic and processual view of chemistry. More so, technology-chemistry literacy may foster from issue-based, historical, local environmental (Paderes, 2018), and social context of chemistry that results into reconceptualization of the nature of science itself (Erduran \& Dagher, 2014) particularly noted as cultural construction in chemical enterprise (Bensaude-Vincent \& Simon, 2008).

Subsequently, since chemistry deals with abstract knowledge, a notable way to acquaint its concept might be according to its three levels namely macroscopic, submicroscopic, and symbolic. This triplet is considered to be a powerful and productive metaphor in teaching chemistry (Talanquer 2011; Talanquer 2018). This triplet was instigated into pedagogy as experiences, models, and visualization. Experiences refer to the descriptive knowledge about the substances and chemical processes acquired directly using human senses. Models regard as explanatory and predictive 
theories that describes chemical system. Lastly, Visualization involves static and dynamic signs of symbols to icons that communicates the first two among the triplets. To further contextualize, an instructor might consider this triplet example provided directly by Talanquer:

Experience (macroscopic): Natural gas burns in the presence of air and can be used to warm things up.

Model (submicroscopic): Natural gas is mainly composed of methane, a chemical compound that undergoes a combustion reaction with a chemical element in the air, oxygen, producing to new substances, carbon dioxide and water, and releasing energy in the forms of heat and light.

Visualization (symbolic): $\mathrm{CH}_{4}(\mathrm{~g})+2 \mathrm{O}_{2}(\mathrm{~g}) \rightarrow \mathrm{CO}_{2}(\mathrm{~g})+2 \mathrm{H}_{2} \mathrm{O}(\mathrm{g})+$ Energy

These three may further enhance by utilizing visual tools and images appropriate for discussion and lesson presentation. Contextualize visuals, molecular models, and atomic structures might be some of the examples. Not just that, but also prerequisite mathematical calculations might be considered as an arithmetic language in understanding abstract chemical knowledge. In fact, a study pointed out that mathematics review predicts general chemistry achievement (Alivio, Howard, Mamiya, \& Williamson, 2020). More so, demonstration supplements the triplet approach in teaching, which has a potential to let the students feel and experience unavailable resources (Meyer, Panee, Schmidt, \& Nozawa). To add, general reasoning and visuospatial representation abilities contributes to students' conception and errors in chemistry (Wu \& Shah, 2003).

Furthermore, expanding conception in chemistry might be initiated through laboratory works and inquiry-based field activities. Knowing the fact that chemistry itself is an abstract and symbolic science (Talanguer, 2011), deviation from traditional teaching would be vital in translating this complex chemistry content into various observable ways and quantifiable terms. In this way, development of their epistemic conception into other profile zones will be generated. Though it was pointed out that hands-on laboratory activity must be an essential part of high school chemistry curriculum (Tenaw, 2015), it is a challenge for the country to have an equipped laboratory and adequate laboratory materials, logistics, and technology that will enrich inquirybased tasks and investigatory projects for students (Orbe, Espinosa, \& Datukan, 2018). Alternatively, innovations and other teaching modes were not in equal quality with real life laboratory but found to be effective. For instance, utilization of computer animation builds mental models for visualizing atoms and molecules (Williamson \& Abraham, 1995).

In addition, it is worth mentioning that some literature supports the identified second theme. College or higher chemistry courses expand chemistry knowledge to multifaceted conceptions. The academic performance in college chemistry, certainly, is influenced by STEM students' previous knowledge from high school chemistry (Tai, Sadler, \& Loehr, 2005). It is necessary to point out Bruner's Discovery Theory, as cited in a local study (Fajardo \& Bacarrisas, 2017), which supports the idea that instruction for high school to college should be in spiral progression so that learners may comprehend concepts easily because learning is active and students are continuously constructing concepts based on prior knowledge. In the country, junior high school science has been in spiral progression. Spiral progression means science subjects were taught interconnectedly and not as separate subject, increasing complexity as the grade level progresses. It seems that this is the major reason why tertiary chemistry for majors, health-allied, engineer, and other STEM related degree programs are directly connected to high school chemistry in a spiral way (CHED, 2012). 
Tertiary chemistry usually contains both lecture course and laboratory course, which deal with indepth problem skills and conceptual understanding in the fundamental and/or advanced chemical sub-fields of inorganic, organic, analytical, physical, and biochemistry. More so, introductory mathematics and physics are also pre-requisite to chemistry problems. In addition, skills to infer precise and accurate measurement in one of the abilities should be learned by the course takers (CHED, 2012). With these learning competencies, chemical thinking, reasoning, and cognition will authentically express by the students in different academic tasks and driving them to consider other views of the discipline. This was explained in a certain study (Erduran \& Dagher, 2014), implying that chemistry in university level is a chance for students to engage in implementing, designing, and evaluating chemical substances into real-life setting. This serves as an opportunity for them to avoid the narrow and limited perspective in chemistry.

In all of these teaching approaches and deepening of knowledge, chemistry teachers should be mindful and cautious in employing pedagogical techniques because the complexity of chemistry (Taber \& Garcia-Franco, 2010) might bring and lead to misconceptions instead of multifaceted conceptions.

\section{CONCLUSION}

The result of the study reveals that almost all of the selected $(n=57)$ senior high school STEM students can conceptualize the epistemic view of chemistry in the profile zone. It is not unusual, knowing the fact that introductory and fundamental high school chemistry deals with symbolical calculation and abstraction of unfamiliar science vocabulary. However, some learners cannot conceptualize chemistry under the other five profile zones. This finding is not a pessimistic and discouraging point but rather serves as an avenue for chemistry instructors and curriculum developers to establish a more meaningful and authentic pedagogy, as long as they were able to recognize the multifaceted view of the discipline. Certainly, the themes generated from the analysis might account and problematize these points: (1) increasing the engagement in chemistry improves conception and (2) taking higher or college chemistry expands chemistry knowledge.

All the data gathered in this study were limited to a relatively small sample size and to just one non-sectarian private school in Manila City. It is recommended to acquire similar data from other universities and institution to expand the baseline information about the multifaceted conception of students in chemistry. Additionally, other chemistry teacher-researchers could do a similar investigation that could serve as a framework for their own class instruction and improvement of practice. This might provide implicit data on how the teacher and instruction significantly affect students' chemistry conceptual profile.

The study implies that there is always an opportunity for critical reflection on how to reconceptualize the discipline and take chemistry into a more authentic field of science and science education.

\section{REFERENCES}

Abd-El-Khalick F. Teaching with and about nature of science, and science teacher knowledge domains. Sci Educ. 2013 Sep; 22(9):2087-2107. https://doi.org/10.1007/s11191-012-9520-2

Adu-Gyamfi K, Ampiah JG, Agyei DD. High school chemistry students' alternative conceptions of $\mathrm{H} 2 \mathrm{O}, \mathrm{OH}-$, and $\mathrm{H}+$ in balancing redox reactions. Int J Dev Sustain. 2015; 4(6):744-758. Available

from https://www.researchgate.net/publication/306012484 High school chemistry students' altern ative conceptions of $\mathrm{H} 2 \mathrm{O} \mathrm{OH}$ - and $\mathrm{H}$ in balancing redox reactions 
Alivio TEG, Howard E, Mamiya B, Williamson VM. How does a math review impact a student's arithmetic skills and performance in first-semester general chemistry? J Sci Educ Technol. 2020 Aug; 29:703-712. https://doi.org/10.1007/s10956-020-09851-7

Atabek-Yigit E. Can cognitive structure outcomes reveal cognitive styles? A study on the relationship between cognitive styles and cognitive structure outcomes on the subject of chemical kinetics. Chem Educ Res Pract. 2018 Apr; 19:746-754. https://doi.org/10.1039/C8RP00018B

Bensaude-Vincent B, Simon J. Chemistry — The Impure Science. Published by Imperial College Press and Distributed by World Scientific Publishing Co.; 2008.

Braun V, Clarke V. Successful qualitative research: A practical guide for beginners. London SAGE Publications; 2013.

Cardellini L. Chemistry: Why the subject is difficult? Educación Química. 2012 May; 23(2):1-6. https://doi.org/10.1016/S0187-893X(17)30158-1

Caulfield J. How to do thematic analysis [Internet]. 2019. Available from: https://www.scribbr.com/methodology/thematic-analysis/

Chamizo JA. Technochemistry: One of the chemists' ways of knowing. Foundations of Chemistry. 2013 Jul 15; 15:157-170. https://doi.org/10.1007/s10698-013-9179-Z

CHED. CHED memorandum order (CMO) no. 41. [Internet]. 2012. Available from: https://ched.gov.ph/wp-content/uploads/2017/10/CMO-No.41-s2012.pdf

Chiu MH. A national survey of students' conceptions of chemistry in Taiwan. Int J Sci Educ. 2007 Mar; 29(4):421-452. https://doi.org/10.1080/09500690601072964

Demircioglu G, Ayas A, Demircioglu H. Conceptual change achieved through a new teaching program on acids and bases. Chem Educ Res Pract. 2005 Jan; 6(1):36-51. https://doi.org/10.1039/B4RP90003K

DepEd. Curriculum Guide for General Chemistry [Internet]. 2016. Available from: https://www.deped.gov.ph/wp-content/uploads/2019/01/General-Chemistry-1-and-2.pdf

Ebenezer JV, Erickson GL. Chemistry students' conceptions of solubility: A phenomenography. Sci Educ. 1996 Apr; 80(2):181-201. https://doi.org/10.1002/(SICI)1098237X(199604)80:2<181::AID-SCE4>3.0.CO;2-C

Erduran S. Dagher ZR, Reconceptualizing the nature of science for science education. Springer: Switzerland, 2014. Available from: https://www.springer.com/gp/book/9789401790567

Fajardo MTM. Bacarrisas PG. First-year college students' knowledge in chemistry: Is it adequate? Am J Educ Res. 2017 Oct; 5(10):1039-1043. https://doi.org/10.12691/education-5-10-5

Freire M, Amaral E. Analyzing conceptions on chemistry: proposal for a conceptual profile. In: European Science Education Research Conference. Dublin City; 2017.

Freire M, Talanquer V, Amaral E. Conceptual profile of chemistry: a framework for enriching thinking and action in chemistry education. Int J Sci Educ. 2019 Mar ; 41(5):674-692. https://doi.org/10.1080/09500693.2019.1578001 
Fugard AJB, Potts HWW. Supporting thinking on sample sizes for thematic analyses: a quantitative tool. Int J Soc Res Methodol. 2015 Feb; 18(6): 669-684. https://doi.org/10.1080/13645579.2015.1005453

Garnett PJ, Garnett PJ, Hackling MW. Students' alternative conceptions in chemistry: A review of research and implications for teaching and learning. Stud Sci Educ. 1995 Jan; 25(1): 69-96. https://doi.org/10.1080/03057269508560050

Hesse JJ, Anderson CW. Students' conceptions of chemical change. J Res Sci Teach. 1992 Mar; 29(3): 277-299. https://doi.org/10.1002/tea.3660290307

Meyer LS, Panee D, Schmidt S, Nozawa F. Using demonstrations to promote student comprehension in chemistry. J Chem Educ. 2003 Apr; 80(4):431. https://doi.org/10.1021/ed080p431

Mortimer EF. Conceptual change or conceptual profile change? Sci Educ. 1995 Jul; 4:267-285. https://doi.org/10.1007/BF00486624

Mortimer EF, El-Hani CN. Conceptual profiles: A theory of teaching and learning scientific concepts. Dordrecht: Springer; 2014. https://doi.org/10.1007/978-90-481-9246-5

Orbe JR, Espinosa AA, Datukan JT. Teaching chemistry in a spiral progression approach: Lessons from science teachers in the Philippines. Aust J Teac Educ. 2018 Apr; 43(4):17-30. Available from: https://ro.ecu.edu.au/cgi/viewcontent.cgi?article $=3678 \&$ context $=$ ajte

Osman K, Sukor NS. Conceptual understanding in secondary school chemistry: A discussion of the difficulties experienced by students. Am J Appl Sci. 2013 May 1; 10(5): 433-441. https://doi.org/10.3844/ajassp.2013.433.441

Özmen H. Some student misconceptions in chemistry: A literature review of chemical bonding. J Sci Educ Technol. 2004 Jun; 13:147-159. https://doi.org/10.1023/B:JOST.0000031255.92943.6d

Paderes NM. Green chemistry perspective among STEM 12 senior high school students. IAMURE Int J Ecol Conserv. 2018; 24(1). [Internet] Available from: https://ejournals.ph/article.php?id=13993

Sadi O. The Analysis of High School Students' Conceptions of Learning in Different Domains. Int J Environ Sci Educ. 2015; 10(6):813-827. Available from https://files.eric.ed.gov/fulltext/EJ1082066.pdf. Doi: 10.12973/ijese.2015.278a

Schmidt H-J, Marohn A, Harrison AG. Factors that prevent learning in electrochemistry. J Res Sci Teach. 2007 Feb; 44(2):258-283. https://doi.org/10.1002/tea.20118

Schummer J, Bensaude-Vincent B, van Tiggelen B. The Public Image of Chemistry. World Scientific; 2007. https://doi.org/10.1142/6636

Sjöström J. Beyond classical chemistry: subfields and metafields of the molecular sciences. [Internet]. Chemistry International; 2006. Available from: https://www.semanticscholar.org/paper/Beyond-Classical-Chemistry\%3A-Subfields-and-ofthe-Sjöström/8c9d728e01b0839ca0b78945bf9724bc34de70d3 
Solis-Foronda M. Readiness, difficulty, and competency in general chemistry: Basis for developing an enrichment strategy. IAMURE Int J Multidiscip Res. 2013; 7(1). [Internet] Available from: https://ejournals.ph/article.php?id=2601

Statistics Solution. Using Chi-Square Statistic in Research [Internet]. 2020. Available from: https://www.statisticssolutions.com/using-chi-square-statistic-in-research/

Taber KS, García-Franco A. Learning processes in chemistry: drawing upon cognitive resources to learn about the particulate structure of matter. J Learn Sci. 2010 Jan; 19(1):99-142. https://doi.org/10.1080/10508400903452868

Tai RH, Sadler PM, Loehr JF. Factors influencing success in introductory college chemistry. J Res Sci Teach. 2005 Nov; 42(9): 987-1012. https://doi.org/10.1002/tea.20082

Talanquer V. Macro, submicro, and symbolic: The many faces of the chemistry "triplet." Int J Sci Educ. 2011 Jan; 33(2): 179-195. https://doi.org/10.1080/09500690903386435

Talanquer V. Chemical rationales: another triplet for chemical thinking. Int J Sci Educ. 2018 Oct 13; 40(15):1874-1890. https://doi.org/10.1080/09500693.2018.1513671

Tenaw YA. Effective strategies for teaching chemistry. Int J Educ Res Rev. 2015 May; 3(3):78-84. Available from: https://internationalscholarsjournals.org/download.php?id=763893143234185337.pdf\&type=ap plication/pdf\&op $=1$

Weingart P. Chemists and their craft in fiction film. Hyle - Int J Philo Chem. 2006; 12(1):31-44. Available from: http://www.hyle.org/journal/issues/12-1/weingart.htm

Williamson VM, Abraham MR. The effects of computer animation on the particulate mental models of college chemistry students. J Res Sci Teach. 1995 May; 32(5): 521-534. https://doi.org/10.1002/tea.3660320508

Wu H-K, Shah P. Exploring visuospatial thinking in chemistry learning. Sci Educ. 2004 May; 88(3): 465-492. https://doi.org/10.1002/sce.10126

Zoller U, Tsaparlis G. Higher and lower-order cognitive skills: The case of chemistry. Research in Science Education. 1997 Mar;27(1). https://doi.org/10.1007/BF02463036 